\title{
Finance-growth nexus in sub-Saharan Africa
}

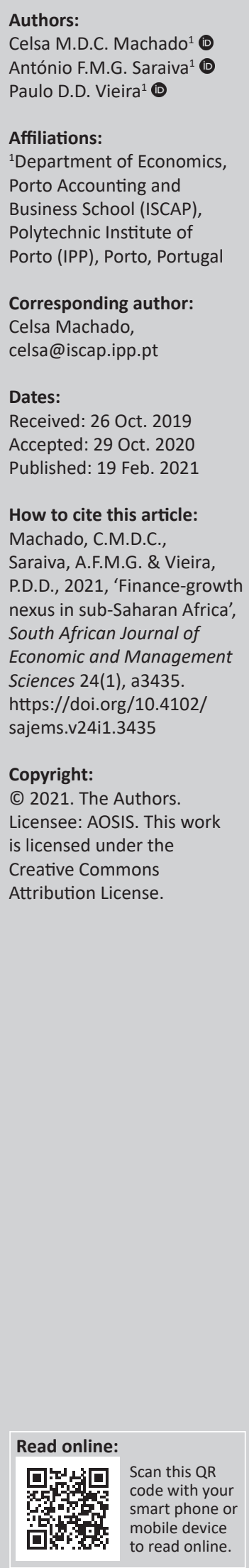

Background: There is now significant empirical literature suggesting that finance is good for growth only up to a threshold level of financial development, becoming harmful after that level, in developed and developing countries.

Aim: This study extends this literature that investigates non-linearities on the finance-growth link, by testing the inverted $U$-shape hypothesis in sub-Saharan African countries, which are among the least developed ones.

Setting: 36 countries from sub-Saharan Africa over the period 1980-2015.

Method: Estimation of quadratic dynamic panel data models by system-generalised method of moments.

Results: Empirical results show that there is a hump-shaped relationship between financial development and economic growth in sub-Saharan African countries.

Conclusion: Results suggest that the hypothesis of 'too much finance harms economic growth' also holds for low-income and less developed countries, but for much lower threshold levels of financial development than those of more developed and higher-income countries. As for policy implications, measures to strengthen finance quality and other growth-enhancing strategies need to be undertaken, rather than increasing finance size.

Keywords: Financial development; economic growth; sub-Saharan Africa; non-linearity; dynamic panel model.

\section{Introduction}

An extensive literature has examined the impact of financial development on economic growth. ${ }^{1}$ A significant branch found empirical evidence of a positive relationship between financial development and economic growth, suggesting 'more finance, more growth' (e.g. Beck, Levine \& Loayza 2000; King \& Levine 1993a, 1993b; Levine, Loayza \& Beck 2000). Indeed, most arguments rely on the fact that a more developed financial system reduces information, transaction and monitoring costs while improving the allocation of capital and risk-taking across the economy. These gains exert positive effects on economic growth by increasing investment and its quality, through affecting its composition and encouraging innovation.

However, the financial sector also competes for physical capital and high-skilled labour with the rest of the economy and that may distort the allocation of resources, draining the more qualified from the productive sectors of the economy. Additionally, a malfunctioning financial system may discourage saving, encourage speculation and benefit low-productivity projects, thus decreasing investment and its quality. The subsequent negative effects on economic growth are more likely to dominate when the financial sector is too large, giving support to the hypothesis that 'too much finance harms economic growth'. ${ }^{2}$

The global financial and economic crisis of 2007-2008 provides evidence of the negative consequences of a large, high-developed, though malfunctioning, financial sector. Therefore, there is now significant empirical literature that assesses the existence of a hump-shaped relationship between financial development and economic growth in developed and developing countries where the financial system is relatively developed (e.g. Arcand, Berkes \& Panizza 2015; Benczúr, Karagiannis \& Kvedaras 2019; Cecchetti \& Kharroubi 2012; Law \& Singh 2014; Samargandi, Fidrmuc \& Ghosh 2015). At large, this literature suggests that finance improves 1.Levine (2005), Beck (2011, 2013), Pasali (2013), Panizza (2014), Fernandez and Tamayo (2017) and Popov (2017), among others, provide comprehensive surveys on this literature.

2.Arcand et al. (2015), Ductor and Grechyna (2015) and Popov (2017) systematise some theoretical channels that support this hypothesis. 
growth only up to a threshold level of financial development and that it becomes harmful beyond that level.

The argument that some critical levels of financial and economic development, human capital or political institutions' quality are required to make economic growth benefit from financial development also echoes in the literature that addresses the presence of nonlinearities in the finance-growth nexus. Some of this empirical literature suggests that, in less developed and low-income countries, the relationship between financial development and economic growth is not significant, while it becomes positive and significant for relatively more developed and higher-income countries (e.g. Deidda \& Fattouh 2002; Rioja \& Valev 2004b).

In the case of African countries, characterised, on average, by low levels of financial development, there is now a growing body of empirical literature that investigates the potential role of financial development in economic growth, by resorting to an array of panel data econometric techniques (e.g. Adusei 2013; Bist 2018; Effiong 2015; Ehigiamusoe \& Lean 2018; Ibrahim \& Alagidede 2018; Inoue \& Hamori 2016; Ngongang 2015). However, to the best of our knowledge, only Ibrahim and Alagidede (2018) assess the existence of a non-linear relationship for a sample of 29 sub-Saharan African (SSA) countries during the period 1980-2014. Their findings lend support to the hypothesis that financial development has a positive and significant impact on growth, only when initial income, financial development or human capital are sufficiently high.

Many African countries have recently experienced extensive reforms in the financial sector that made the access to financial services more widespread and increased financial sector depth (Demirgüç-Kunt \& Klapper 2012). In consequence of such reforms, access to financial services has grown faster in the SSA countries that were among the countries with the lowest records in this matter (Inoue \& Hamori 2016). ${ }^{3}$ A larger dissemination of financial services, promoted by the successful adherence to new technologies, such as mobile money, together with the financial deepening of credit, contributed to the development of SSA countries' financial sectors.

Despite the development of the financial sector in SSA, important informal methods of saving and borrowing still coexist with formal ones. Moreover, Demirgüç-Kunt and Klapper (2012) show that, when compared to other developing economies, high-growth small and medium firms are less likely to use formal financing, suggesting that formal financial systems may not be serving the needs of firms facing growth opportunities. Hence, in SSA countries, it may be the case that the relative dimension of the financial sector is underestimated when one uses the typical measures of (formal) financial development. Apparently, it may also

3.Effectively, financial access, proxied by the number of commercial bank branches per 100000 adults in the period 2004-2012, increased at an average annual rate of $6.7 \%$ in SSA countries, compared to only $2 \%$ in the world (Inoue \& Hamori 2016). be the case that the projects benefiting from formal financing funds may not be the most productive and growth-enhancing ones. Therefore, relying on the empirical evidence of an inverted $U$-shaped relationship between financial development and growth for high- and middle-income countries, we conjecture that parallel evidence would also hold in low-income countries, such as SSA countries, but certainly for lower threshold levels of financial development. The low levels of physical and human capital and the weak institutional quality that characterise these countries are additional factors that may contribute to a (still) underdeveloped financial sector becoming excessive.

In line with these arguments, this article extends recent empirical literature that investigates non-linearities in the link between financial development and economic growth, by testing the inverted $U$-shaped hypothesis in countries that are among the least developed ones, such as the SSA countries. It contributes to the existing literature in three aspects. Firstly, to the best of our knowledge, we present the first attempt to investigate this pattern of nonlinearity in this region, by applying the Cecchetti and Kharroubi (2012) non-linear modelling strategy to a panel of 36 SSA countries, over the period 1980-2015. Secondly, as estimation strategy, we use a dynamic panel systemgeneralised method of moments (SYS-GMM) estimator, which allows us to control for potential endogeneity problems. Thirdly, we use the Lind and Mehlum (2010) $U$-test, which is more appropriate to validate the inverted $U$-shaped relationship than conventional tests.

Our results suggest that more finance may be growthdepleting, even for countries with (still) low levels of financial development. To get positive growth effects from 'more finance', complementary reforms may be required: institutional quality and economic reforms should be pursued together with those in the financial system. 'More finance' needs to be supported by 'better finance'.

The rest of the article is structured as follows. Section 2 reviews relevant literature on the finance-growth nexus. Section 3 specifies the model, describes the data and the econometric methodology. Section 4 presents and discusses empirical results. Section 5 provides main conclusions.

\section{Literature review}

The services provided by the financial sector might contribute to economic growth by: (1) producing ex-ante information about potential investments, (2) monitoring investment and enhancing corporate governance, (3) facilitating risk management and diversification, (4) mobilising and pooling savings, and (5) easing the exchange of goods and services (Levine 2005). Essentially, by reducing information, transaction and monitoring costs and improving the allocation of capital and risk across the economy, financial development increases investment and improves its quality, and thus exerts a positive effect on economic growth, 
suggesting a positive relationship between financial development and economic growth. ${ }^{4}$

However, there is also the possibility that financial development distorts resource allocation, discourages saving, encourages speculation, and favours unproductive projects, decreasing investment and its quality, and thus exerts a negative effect on economic growth. Negative effects are likely to coexist with positive ones and might explain non-linearities on the finance-growth nexus. There is a strand of theoretical literature that identifies the sources of a non-linear relationship between finance and growth relying only on financial development itself, while another strand of the literature, instead, emphasises the role of mediating factors on such non-linearity.

In line with the first strand of literature, a first important argument for the non-linearity of the finance-growth nexus is the suboptimal allocation of talents that results from a large financial sector. According to Tobin (1984), the private returns of the financial sector are higher than the social ones. Bolton, Santos and Scheinkman (2016) provide a theoretical model where the financial industry extracts excessively high rents from the provision of financial services and these rents attract too much talent. Therefore, a larger financial sector, competing for more qualified resources with the rest of the economy, may drain the 'cream-skimming' resources from the productive sectors, with negative consequences for economic growth.

A second argument relates to financial development, resulting from financial innovation and liberalisation, with the increase of systemic risk which, by exacerbating macroeconomic volatility, impacts negatively on economic growth (see, for instance, Arcand et al. 2015; Ductor \& Grechyna 2015; Popov 2017).

Another argument follows from the segmentation of the credit market between investment and consumption credit markets or between firm and household (especially house mortgage) credit. Hung and Cothren (2002) show that, with credit market imperfections, when screening consumers is cheaper than screening entrepreneurs, financial development initially favours investment and promotes growth. However, when credit markets are further developed, consumers' borrowing constraints are relaxed and net savings decrease more substantially, and this attenuates the effects of financial development on economic growth. This model predicts that the effects of credit market development on growth are more effective in countries with lower levels of financial development than in those with higher levels of financial development. In turn, Hung (2009) develops a more general model, aiming to replicate all the non-linear patterns found by recent empirical literature, of the finance-growth nexus. In his model, financial development facilitates both investment loans and consumption loans with opposite impacts on

4.Greenwood and Jovanovic (1990) Bencivenga and Smith (1991) Pagano (1993) and Acemoğlu and Zilibotti (1997) are examples of theoretical contributions Acemoglu and Zilibotti (1997) are examples of theoretical contributions
demonstrating the role of financial development in promoting investment and the improvement of its efficiency. economic growth. The net effect on economic growth depends on the relative magnitudes of these two channels which hinge on the initial level of financial development. In countries with low levels of financial development, there is uncertainty on which effect dominates and thus the effect of financial development on economic growth is also uncertain. However, in countries with intermediate levels of financial development, the relationship between finance and growth is positive because the effect of investment loans clearly dominates. Finally, in countries with high levels of financial development, the effect of consumption loans increases with the level of financial development and once more there is uncertainty about which effect dominates. However, even if the investment loans effect dominates, the positive net effect on economic growth becomes smaller than that for countries with intermediate levels of financial depth.

Along these theoretical arguments, there is substantial literature that finds empirical evidence of a non-linear relationship between financial development and economic growth. Typically, in most empirical studies, measures of banking sector development, such as the ratios of private sector credit or of liquid liabilities to gross domestic product (GDP), are employed as measures of financial development, while the financial sector encompasses other types of financial institutions and markets. At large, this literature suggests that finance is good for growth only up to a threshold level of financial development, becoming harmful beyond that level, giving support to the so-called 'too much finance' hypothesis. ${ }^{5}$ However, this threshold level varies significantly across the different studies. While Swamy and Dharani (2019) found, using a sample of 24 advanced economies, that more finance hinders growth when the domestic credit to private sector ratio exceeds a level of $142 \%$ of GDP, Benczúr et al. (2019) found, also in high-income economies, threshold levels ranging from $37 \%$ to $46 \%$ and $61 \%$ to $76 \%$, depending on the group of countries and on how financing is decomposed. For more comprehensive samples of developed and developing countries, Arcand et al. (2015), Cecchetti and Kharroubi (2012) and Law and Singh (2014) found that credit to the private sector is expected to start having negative effects on output growth when it reaches threshold levels of 100\%, 99\% and $88 \%$ of GDP. In turn, Samargandi et al. (2015), in a panel of middle-income countries and using the threshold method, found that, for the whole sample and the upper-middle income subsample, the estimated threshold value of the financial development indicator is around $92 \%$ of GDP, while it decreases to $43 \%$ for lower middle-income countries. Soedarmono, Hasan and Arsyad (2017), from a panel data set of provinces of Indonesia over the period 2000-2009, document inverted $U$-shaped relationships between total credit, investment credit and, to a lesser extent, consumption credit and the regional economic growth, but with much lower threshold levels. Their different measures of financial depth start to hamper regional output growth when they

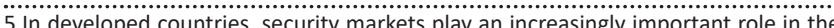
process of econic devith process of econich by banks (cf. Demirguç-Kunt, Feyen \& Levine 2013). Arcand et al. (2015) claim that this may provide a rationale for a 'too much credit' hypothesis rather than the 'too much finance' hypothesis, as it may be the case of a wrong structure of finance with a disproportionate size of banks relative to markets. 
reach threshold levels ranging from $18 \%$ to $40 \%$. According to these authors, if the majority of loans are allocated to sectors that contribute less to economic growth, such as wholesale and retail trade sectors in Indonesia, then more credit might have adverse consequences on growth and become 'too much', even for relatively low levels of financial depth.

Rioja and Valev (2004a), using a panel of 74 developed and developing countries, found a different non-linear pattern in the finance-growth nexus, as predicted by the theoretical model of Hung (2009). More specifically, the effect of financial development produced: (1) an uncertain effect on economic growth for countries with low levels of financial development, (2) a significantly positive effect for countries with intermediate levels of financial development and (3) a positive, but small, effect for countries with high levels of financial development.

Another strand of theoretical and empirical literature asserts the importance of mediating factors to explain non-linearity on the finance-growth relationship. The conditioning effect of political and economic institutions on the finance-growth nexus is emphasised by, for instance, Demetriades and Law (2006), Gazdar and Cherif (2015) and Slesman, Baharumshah and Azman-Saini (2019), while that of the economic development stage receives empirical support from Deidda and Fattouh (2002), Rioja and Valev (2004b) and Ibrahim and Alagidede (2018), among others. ${ }^{6}$

For instance, Slesman et al. (2019) posit that empirical evidence of a non-linear relationship between finance and growth in developing countries may have missed the contingent role played by political institutions. They found robust evidence that a critical threshold level of political institutions is required for economic growth to benefit from financial development in developing countries, where political institutions are known to be relatively weak and the levels of financial development low. In turn, Ibrahim and Alagidede (2018) claim that the initial level of income is a key potential threshold variable mediating how finance affects economic growth. For a panel of 29 SSA countries, their results suggest that, in less developed and low-income countries, the relationship between financial development and economic growth is not significant, while it becomes positive and significant for relatively more developed and higher-income countries. More generally, Ibrahim and Alagidede provide evidence that financial development has a positive and significant impact on growth, only when economies are above some threshold levels of initial income, financial development or human capital; below these threshold levels, there is no significant impact of financial development on growth.

6.Other mediating factors have been explored in recent empirical literature. Domb and Grigoriadis (2020) investigate the role of ancestral institutions and historical legacies in the finance-growth relationship in post-Soviet countries, while Adusei legacies in the finance-growth relationship in post-Soviet countries, while Adusei
(2019) investigates the role of the risk premium in the finance-growth link, using data from South Africa.

\section{Data and methodology Model specification and data description}

In line with Cecchetti and Kharroubi (2012), but within a dynamic model, we assume the following standard quadratic relationship between financial development and economic growth:

$$
\begin{aligned}
\text { growth }_{i, t}= & \alpha_{i}+\beta_{0} \text { growth }_{i, t-1}+\beta_{1}\left(\ln F D_{i, t}\right)+\beta_{2}\left(\ln F D_{i, t}\right)^{2}+ \\
& \boldsymbol{\varphi} \boldsymbol{X}_{i, t}+\theta_{t}+\varepsilon_{i, t}
\end{aligned}
$$

In Equation 1 growth $_{i, t}$ refers to GDP growth rate in the $i$ th country at time $t$. $\ln F D_{i, t}$ is the natural logarithm of the country's level of financial development, $X_{i, t}$ represents the vector of control variables, $\alpha_{i}$ is the unobserved country-specific effect for country $i, \theta_{t}$ is the period effect for time $t$ and $\varepsilon_{i, t}$ is the error term. The control variables used in the model are commonly used in the literature and include initial income, investment, human capital, inflation and an index of institutional quality.

Our major concern is the magnitude and significance of coefficients $\beta_{1}$ and $\beta_{2}$. If the finance-growth relationship follows an inverted $U$-shaped relationship, then $\beta_{1}$ is positive and $\beta_{2}$ negative. To estimate the model and to test this hypothesis, we use a panel data sample of 36 SSA countries for the period 1980-2015.7 In order to purge business cycle frequencies from the data, the data set is averaged for nonoverlapping periods of 5 years, which allows for a maximum of seven observations per country (1981-1985, 1986-1990, 1991-1995, 1996-2000, 2001-2005, 2006-2010, 2011-2015).

Table 1 describes the variables, and corresponding sources, used in the model. Economic growth (growth) is proxied by percentage changes in real GDP per capita. Two different variables are used as measures of financial development (FD): the domestic credit to the private sector (DC) and liquid liabilities, commonly referred to as broad money (M3), all expressed as ratios to GDP. Domestic credit to the private sector refers to loans given by financial institutions to the private sector, that is, it excludes credits issued to governments or its agencies, public enterprises, as well as credits issued by the central bank. Liquid liabilities include currency plus demand and interest-bearing liabilities of banks and nonbanking financial intermediaries. Both indicators of financial development are commonly used as indicators of financial intermediation and financial depth (e.g. Loyaza \& Rancière 2006), although domestic credit is more directly linked to investment and economic growth than liquid liabilities.

As for control variables, the ratio of gross capital formation (GCF) to GDP is used to proxy investment and physical capital accumulation, while the index of human capital (HC) is a per worker index based on the average years of schooling and on the rate of return for primary, secondary and tertiary

7.We considered 36 out of 46 SSA countries; these are the only ones with data available for the index of human capital. The list of countries is presented in a note to Table 2 . 
TABLE 1: Definitions and sources of variables.

\begin{tabular}{|c|c|}
\hline Notation & Description \\
\hline growth & Real GDP per capita percentage growth - World Development Indicators \\
\hline $\ln D C$ & $\begin{array}{l}\text { Natural logarithm of domestic credit to the private sector over } \\
\text { GDP - World Development Indicators }\end{array}$ \\
\hline $\ln M 3$ & $\begin{array}{l}\text { Natural logarithm of broad money to GDP - World Development } \\
\text { Indicators }\end{array}$ \\
\hline InGDPO & $\begin{array}{l}\text { Natural logarithm of GDP per capita (constant price in US\$, 2010) } \\
\text { for the initial year of each 5-year sub-period - World Development } \\
\text { Indicators }\end{array}$ \\
\hline $\mathrm{InHC}$ & $\begin{array}{l}\text { Natural logarithm of the human capital index - Penn World Table, } \\
\text { Version } 9.0\end{array}$ \\
\hline InGCF & $\begin{array}{l}\text { Natural logarithm of the ratio of the gross capital formation to } \\
\text { GDP - World Development Indicators }\end{array}$ \\
\hline inflation & CPI inflation rate - World Development Indicators \\
\hline IL & $\begin{array}{l}\text { Transformation (non-freedom }=0 \text {; partial freedom }=0.5 \text {; freedom }=1 \text { ) } \\
\text { of the index of political rights and civil liberties }- \text { Freedom House: } \\
\text { Freedom in the World } 2017\end{array}$ \\
\hline
\end{tabular}

GDP, gross domestic product.

education, as described by Feenstra, Inklaar and Timmer (2015). Both variables are expected to have a positive effect on growth. The growth rate of the consumer price index (inflation) is used to proxy macroeconomic instability while initial income $\left(\mathrm{GDP}_{0}\right)$, the initial GDP per capita (constant price in US\$, 2010) for each 5-year sub-period, is used to capture absolute convergence effects. These two variables are expected to negatively impact on growth. Finally, we use the Freedom House Index of Political Rights and Civil Liberties (IL) to represent institutional quality, as in Anwar and Cooray (2012). Naturally, better institutions are expected to enhance growth. With the exception of growth, inflation and IL, all variables are transformed into natural logarithms.

\section{Methodology}

Model estimation uses the dynamic panel system GMM estimator developed by Arellano and Bover (1995) and Blundell and Bond (1998). This estimator, requiring a large number of cross-section units and a small number of time periods, was chosen in order to control: (1) country-specific effects, (2) autocorrelation problems, due to the presence of the lagged dependent variable in the model, and (3) simultaneity bias, caused by potential endogeneity of some of the explanatory variables.

Unlike the difference GMM estimator, proposed by Arellano and Bond (1991), this estimator is appropriate when explanatory variables are persistent, as is the case of macroeconomic variables such as financial development, human capital, GDP per capita, investment or inflation, for which corresponding lagged values are seen as weak instruments (see Law, Lee \& Singh 2018, for more elaborated arguments).

We use the two-step system GMM estimator which is asymptotically more efficient than the one-step estimator. The proliferation of instruments in a sample of small crosssection dimensions, as in the present study, may lead to biased standard errors. Therefore, we apply Windmeijer (2005) finite-sample correction to reported standard errors in the two-step estimation, to avoid standard errors being severely downward biased.
To test for the presence of an inverse $U$-shaped relationship between financial development and economic growth in a more appropriate way, we use the test provided by Lind and Mehlum (2010). These authors argue that it is not enough that the first and the second derivatives have opposite signs for having a $U$-shaped or inverted $U$-shaped relationship. This criterion will be misleading when the estimated extreme point is close to the end point or to the starting point of the data range. To validate an inverted $U$-shaped relationship between FD and growth, we test the null hypothesis $\mathrm{H}_{0}$ (Equation 2) against the alternative hypothesis $\mathrm{H}_{1}$ (Equation 3):

$$
\begin{aligned}
& H_{0}: \beta_{1}+2 \beta_{2} \ln F D_{\text {low }} \leq 0 \bigcup \beta_{1}+2 \beta_{2} \ln F D_{\text {high }} \geq 0 \\
& H_{1}: \beta_{1}+2 \beta_{2} \ln F D_{\text {low }}>0 \bigcup \beta_{1}+2 \beta_{2} \ln F D_{\text {high }}<0
\end{aligned}
$$

$\ln F D_{\text {low }}$ and $\ln F D_{\text {high }}$ represent the minimum and maximum values of $\ln F D$.

The inverted $U$-shaped relationship holds, if the null hypothesis is rejected.

\section{Empirical results}

Descriptive statistics presented in Table 2 confirm the small magnitude of the financial sector in these countries: the average domestic credit to the private sector represents only $18.5 \%$ of GDP, while the average liquid liabilities represents $26.4 \%$ of GDP. ${ }^{8}$ Descriptive statistics further indicate that, on average, these countries are low-income countries, with high average inflation (52.4\%) and exhibiting poor institutional quality (the index of political rights and civil liberties averages 0.3 out of 1 ). Records also suggest that countries in the sample are highly heterogeneous. Moreover, correlation coefficients between financial development variables and economic growth, reported in Table 2, are positive but only statistically significant for liquid liabilities. Gross capital formation, human capital and the index of political rights and civil liberties are also positive and statistically significantly correlated with growth during this period, while inflation is negatively correlated.

\section{Analysis of estimation results}

Table 3 reports the results from the two-step system GMM estimation of Equation 1, in its original form and without the financial development quadratic term, using separately domestic credit to private sector $(\ln D C)$ and liquid liabilities $(\ln M 3)$ as proxies for financial development.

Referring to Models 1DC and 1M3, which assume a linear relationship between financial development and economic growth, the results indicate that financial development does not have a statistically significant impact on economic 8. In the sample of 75 developed and developing countries, for the period 1996-2010, used by Law et al. (2018), the mean of the ratio of private sector credit to GDP is $72.9 \%$. 
TABLE 2: Descriptive statistics and correlation matrix.

\begin{tabular}{|c|c|c|c|c|c|c|c|c|}
\hline Variables & Growth & $\mathrm{GDP}_{0}$ & DC & M3 & GCF & Inflation & IL & HC \\
\hline Mean & 0.91 & 1598.42 & 18.46 & 26.44 & 19.07 & 52.48 & 0.39 & 1.58 \\
\hline Standard deviation & 3.94 & 2192.59 & 20.82 & 14.75 & 8.22 & 434.10 & 0.34 & 0.38 \\
\hline Minimum & -21.63 & 115.44 & 0.20 & 0.36 & 0.00 & -2.99 & 0.00 & 1.02 \\
\hline Maximum & 30.74 & 12139.54 & 150.47 & 100.35 & 53.77 & 6517.11 & 1.00 & 2.77 \\
\hline Number of observations & 249 & 246 & 249 & 249 & 236 & 236 & 249 & 249 \\
\hline \multicolumn{9}{|l|}{ Correlation matrix } \\
\hline Economic growth $(\%)$ & 1 & - & - & - & - & - & - & - \\
\hline Initial GDP per capita (constant price in US\$, 2010) & 0.01 & 1 & - & - & - & - & - & - \\
\hline Domestic credit to private sector (\% of GDP) & 0.06 & $0.48 * * *$ & 1 & - & - & - & - & - \\
\hline Liquid liabilities (\% of GDP) & $0.19 * * *$ & $0.38 * * *$ & $0.76 * * *$ & 1 & - & - & - & - \\
\hline Gross capital formation ( $\%$ of GDP) & $0.24 * * *$ & $0.32 * * *$ & $0.14 * *$ & $0.21 * * *$ & 1 & - & - & - \\
\hline Inflation rate $(\%)$ & $-0.29 * * *$ & -0.03 & -0.07 & -0.05 & $-0.12 *$ & 1 & - & - \\
\hline Index of political rights and civil liberties & $0.24 * * *$ & $0.22 * * *$ & $0.37 * * *$ & $0.46 * * *$ & $0.24 * * *$ & -0.11 & 1 & - \\
\hline Human capital index & $0.18 * * *$ & $0.57 * * *$ & $0.42 * * *$ & $0.49 * * *$ & $0.38 * * *$ & -0.05 & $0.42 * * *$ & 1 \\
\hline
\end{tabular}

Note: Countries: Angola, Burundi, Benin, Burkina Faso, Botswana, Central African Republic, Cote d'Ivoire, Cameroon, Democratic Republic of the Congo, Republic of the Congo, Gabon, Ghana, Gambia, Kenya, Liberia, Lesotho, Madagascar, Mali, Mozambique, Mauritania, Mauritius, Malawi, Namibia, Niger, Nigeria, Rwanda, Sudan, Senegal, Sierra Leone, Swaziland, Togo, Tanzania, Uganda, South Africa, Zambia and Zimbabwe.

GDP, gross domestic product; GCF, gross capital formation.

$* * *, * *$ and $*$ denote significance level at $1 \%, 5 \%$ and $10 \%$.

TABLE 3: Two-step system-generalised method of moments estimations.

\begin{tabular}{|c|c|c|c|c|c|c|c|c|}
\hline \multirow[t]{3}{*}{ Variable } & \multicolumn{4}{|c|}{ Financial development, FD $\equiv D C$} & \multicolumn{4}{|c|}{ Financial development, $\mathrm{FD} \equiv \mathrm{M} 3$} \\
\hline & \multicolumn{2}{|c|}{ Model 1DC } & \multicolumn{2}{|c|}{ Model 2DC } & \multicolumn{2}{|c|}{ Model 1M3 } & \multicolumn{2}{|c|}{ Model 2M3 } \\
\hline & Coefficient & $\begin{array}{c}\text { Robust standard } \\
\text { errors }\end{array}$ & Coefficient & $\begin{array}{c}\text { Robust standard } \\
\text { errors }\end{array}$ & Coefficient & $\begin{array}{c}\text { Robust standard } \\
\text { errors }\end{array}$ & Coefficient & $\begin{array}{c}\text { Robust standard } \\
\text { errors }\end{array}$ \\
\hline Growth $_{t-1}$ & $-0.1747 * * *$ & 0.0442 & $-0.1925 * * *$ & 0.0396 & $-0.1911 * * *$ & 0.0627 & $-0.2209 * * *$ & 0.0358 \\
\hline InGDPO & $-5.3089 * * *$ & 1.9435 & $-4.3681 * *$ & 1.9280 & $-5.0221 * * *$ & 1.6035 & $-4.3261 * * *$ & 1.5755 \\
\hline $\operatorname{lnFD}$ & 0.2367 & 0.8015 & $1.9384^{*}$ & 1.1886 & -1.4640 & 1.6692 & $8.8831 * * *$ & 2.5605 \\
\hline $\operatorname{lnFD^{2}}$ & - & - & $-0.5014^{*}$ & 0.3071 & - & - & $-1.7983 * * *$ & 0.4332 \\
\hline Inflation & $-0.0009 *$ & 0.0005 & $-0.0011 * *$ & 0.0005 & -0.0006 & 0.0004 & $-0.0013 * * *$ & 0.0003 \\
\hline IL & $2.2209 *$ & 1.2804 & $1.7749 *$ & 0.9318 & 2.3783 & 1.5346 & 1.5834 & 1.0409 \\
\hline $\ln \mathrm{HC}$ & 0.0384 & 5.5694 & 1.9663 & 4.0703 & -2.0969 & 12.4938 & 1.4989 & 7.2190 \\
\hline Constant & $33.0627 * * *$ & 11.9238 & $26.3215 * *$ & 12.7072 & $37.6408 * * *$ & 14.3190 & 18.5084 & 12.2141 \\
\hline $\operatorname{AR}(2)$ ( $p$-value) & 0.2527 & - & 0.2914 & - & 0.2056 & - & 0.1332 & - \\
\hline Sargan test ( $p$-value) & 0.5265 & - & 0.4290 & - & 0.7500 & - & 0.5451 & - \\
\hline No. of countries & 35 & - & 35 & - & 35 & - & 35 & - \\
\hline No. of instruments & 32 & - & 33 & - & 32 & - & 33 & - \\
\hline Turning point & - & - & $6.9 \%$ & - & - & - & $11.8 \%$ & - \\
\hline Lower bound slope & - & - & $3.5611 * * *$ & - & - & - & $12.5961 * * *$ & - \\
\hline Upper bound slope & - & - & $-3.0897 * * *$ & - & - & - & $-7.6613 * * *$ & - \\
\hline Overall $U$-test ( $t$-value) & - & - & $4.44 * * *$ & - & - & - & $11.62 * * *$ & - \\
\hline
\end{tabular}

Note: Time dummies were jointly significant and are not reported here to save space. Sargan test performed with non-robust standard errors. Dependent variable: Economic growth. Sample period: 1980-2015 (5-year average).

$* * *, * *$ and $*$ denote significance level at $1 \%, 5 \%$ and $10 \%$.

growth, in line with the findings of Effiong (2015) and Ngongang (2015). However, the results of the estimation of a linear relationship are misleading when the true relationship between financial development and economic growth is non-linear, as we hypothesise it to be.

The estimation of Models 2DC and 2M3 show the existence of a non-linear relationship between both financial development indicators and economic growth. The results are in line with the hypothesis that finance delivers a positive impact on growth only up to a certain threshold and that too much finance becomes harmful. Effectively, the coefficients of the linear term of both financial development indicators are positive, while those of quadratic terms are negative (and statistically significant), suggesting the existence of an inverted $U$-shaped relationship between finance and growth. This relationship is validated by the Lind and Mehlum (2010) $U$-test in Table 3. ${ }^{9}$ Therefore, as many studies have demonstrated for the case of more developed and higher-income countries, our estimation suggests that the inverted $U$-shaped relationship between finance and growth also holds for low-income and less developed countries, but on a much lower threshold-level of financial development. According to our point estimate, domestic credit to private sector ratio (\%GDP) becomes harmful to economic growth after a threshold level of $6.9 \%$, while liquid liabilities (\%GDP) become detrimental after

9.The test rejects the null hypothesis of a $U$-shaped profile and the slope of the lower bound is positive while that of the upper bound is negative, both being significant. This validates the existence of an inverted $U$-shaped relationship between finance and growth. 
$11.8 \%$. These two values fall below the means for the two financial indicators reported in Table 2.

Figure 1 and Figure 2 present the graphical representations of Models 2DC and 2M3. They illustrate the inverted $U$-shaped profile between both indicators of financial development and economic growth and show that most observations fall in the descending part of the fitted lines. This suggests an oversized financial sector, even in countries where its relative dimension is, apparently, too small. Such counter-intuitive results may be the consequence of the confluence of many factors: (1) the financial sector's drainage of the scarce 'cream-skimming' resources from productive sectors (e.g. Tobin 1994), (2) the dominance of consumption credit over investment credit (e.g. Hung 2009), (3) the low quality levels of political, legal and economic institutions (e.g. Slesman et al. 2019), (4) unbalanced growth in the financial and real estate (e.g. Ductor \& Grechyna 2015) and (5) a financial structure where informal methods of saving and borrowing compete with the formal financial sector regarding financing high-growth small and medium firms (Demirgüç-Kunt \& Klapper 2012).

Some other empirical studies also have found relatively low threshold levels of financial development: Samargandi et al. (2015) in a subsample of lower-middle

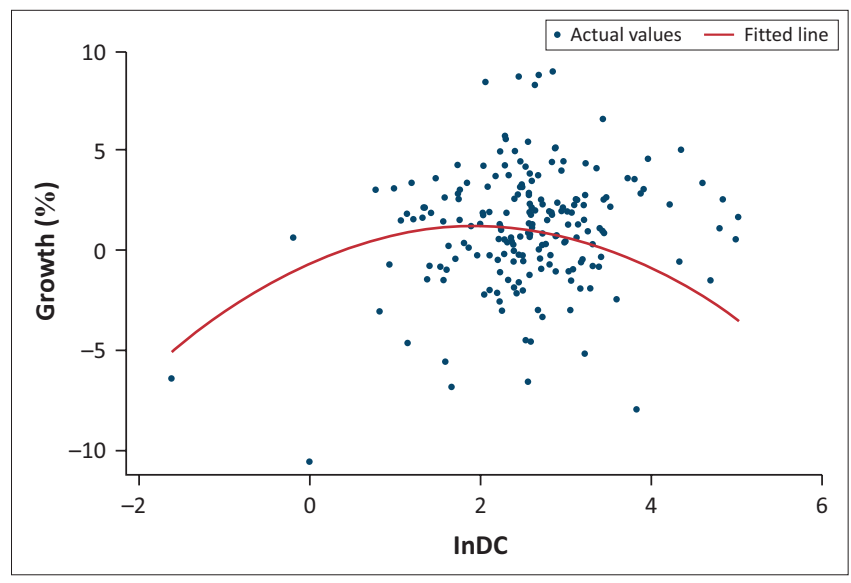

FIGURE 1: Domestic private credit to gross domestic product ratio and growth.

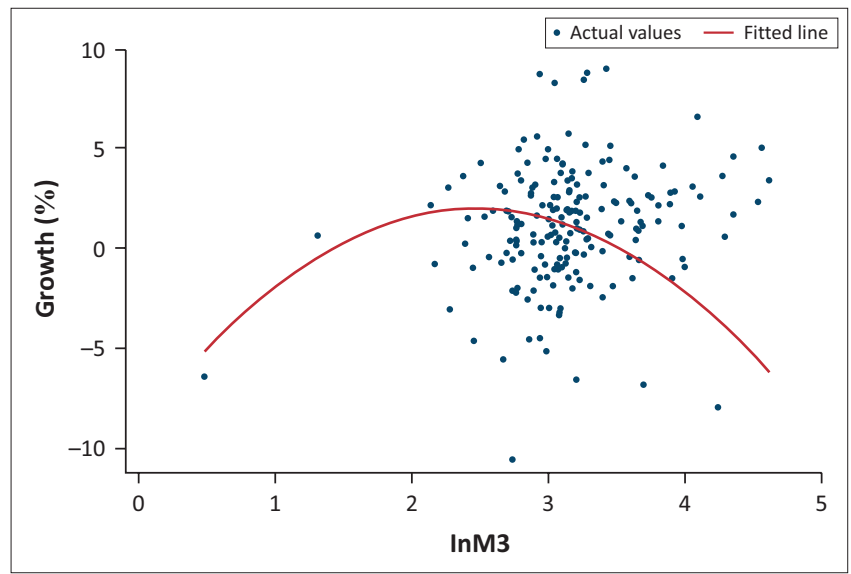

FIGURE 2: Liquid liabilities to gross domestic product ratio and growth. income countries and Soedarmono et al. (2017) for Indonesia, using regional-level data, for instance. However, as for African countries, most panel data studies assume a linear finance-growth nexus with blurred evidence of the significance and signal of this relationship. While, for instance, Adusei (2013) and Ehigiamusoe and Lean (2018) find evidence of a significant and positive relationship between finance and growth, Ngongang (2015) find no statistical significance and Bist (2018) show that private credit has a positive and significant impact on economic growth for 9 out of 16 African countries, no significant impact on four countries and a negative impact on three countries. ${ }^{10}$ However, these results may lose relevance if the true finance-growth nexus is non-linear. Ibrahim and Alagidede (2018) add to this empirical literature by estimating a threshold model and allowing for a non-linear relationship between finance and growth. Based on data from 29 SSA countries over the period of 1980-2014, they find that financial development only has a significant and positive effect on growth after an initial financial development threshold-level, at odds with our results.

Concerning control variables, Table 3 shows that their coefficients have signs consistent with the theory and that they are statistically significant, except for human capital. As expected, more investment and better institutional quality improve economic growth, while a higher initial income and higher inflation lead to lower economic growth.

As for the diagnostic tests, the Sargan test does not reject the null hypothesis of over-identification restriction, suggesting that the instruments are valid. Furthermore, the serial correlation test fails to reject the null hypothesis of no second-order autocorrelation. Overall, both tests suggest that models are relatively well specified.

\section{Robustness checks}

In order to examine the sensitivity of the results, we carried out two robustness checks.

In the first one, additional explanatory variables are included, namely the ratio of government expenditure to GDP $(\ln G)$ and trade openness $(\ln O p e n) .{ }^{11}$ Table 4 presents estimation results of Models 3DC and 3M3, that include $\ln G$ as an additional control variable, and Models 4DC and $4 \mathrm{M} 3$ that, instead, include $\ln O p e n$. The coefficients of these two additional variables are not statistically significant and the results are qualitatively similar to the ones reported in Table 3 .

As a second robustness check, we apply two different estimation methodologies.

10.Acaravci, Ozturk and Acaravci (2009) provide a comprehensive review of empirical literature on SSA.

11.Natural logarithm of the ratio of the general government expenditure to GDP (InG); natural logarithm of the ratio of exports plus imports to GDP (InOpen). Both indicators were obtained from World Bank, World Development Indicators (WDI). 
TABLE 4: Two-step system-generalised method of moments estimations with an additional explanatory variable.

\begin{tabular}{|c|c|c|c|c|c|c|c|c|}
\hline \multirow[t]{3}{*}{ Variable } & \multicolumn{4}{|c|}{ Financial development, FD $\equiv D C$} & \multicolumn{4}{|c|}{ Financial development, FD $\equiv \mathrm{M} 3$} \\
\hline & \multicolumn{2}{|c|}{ Model 3DC } & \multicolumn{2}{|c|}{ Model 4DC } & \multicolumn{2}{|c|}{ Model 3M3 } & \multicolumn{2}{|c|}{ Model 4M3 } \\
\hline & Coefficient & $\begin{array}{l}\text { Robust standard } \\
\text { errors }\end{array}$ & Coefficient & $\begin{array}{l}\text { Robust standard } \\
\text { errors }\end{array}$ & Coefficient & $\begin{array}{l}\text { Robust standard } \\
\text { errors }\end{array}$ & Coefficient & $\begin{array}{l}\text { Robust standard } \\
\text { errors }\end{array}$ \\
\hline Growth $_{\mathrm{t}-1}$ & $-0.2042 * * *$ & 0.0430 & $-0.1833^{* * *}$ & 0.0630 & $-0.2251 * * *$ & 0.0381 & $-0.2089 * * *$ & 0.0454 \\
\hline InGDPO & $-4.0536 * *$ & 2.0108 & $-4.9691 *$ & 2.6083 & $-4.1147 * *$ & 1.6322 & $-4.8990 * * *$ & 1.5819 \\
\hline $\ln F D$ & $2.1140 *$ & 1.2459 & $2.6089 * * *$ & 0.9998 & $9.1632 * * *$ & 2.7182 & $9.9747 * * *$ & 2.2917 \\
\hline $\ln F D^{2}$ & -0.4975 & 0.3197 & $-0.6293 * * *$ & 0.2389 & $-1.8199 * * *$ & 0.4493 & $-1.8775 * * *$ & 0.3956 \\
\hline InGCF & $1.2276 *$ & 0.6438 & 2.1681 & 1.2946 & $1.1384 * *$ & 0.4962 & $1.8520 *$ & 1.0731 \\
\hline Inflation & $-0.0010 * *$ & 0.0005 & $-0.0007 * * *$ & 0.0002 & $-0.0012 * * *$ & 0.0003 & $-0.0011 * * *$ & 0.0001 \\
\hline IL & $2.0244 *$ & 1.1325 & $2.7163 * *$ & 1.3498 & $1.7505^{*}$ & 1.0766 & 2.1303 & 1.4527 \\
\hline $\mathrm{InHC}$ & 0.7834 & 6.1795 & -0.1002 & 13.9122 & 0.4432 & 6.1428 & 1.1683 & 6.7366 \\
\hline $\ln G$ & -1.2941 & 0.9164 & - & - & -0.6006 & 1.0313 & - & - \\
\hline InOpen & - & - & -2.8072 & 1.7679 & - & - & -2.1493 & 1.4240 \\
\hline Constant & $27.1041 * *$ & 13.0017 & $38.7994 * *$ & 19.7487 & $15.8844 * *$ & 11.4139 & $26.3698 * *$ & 11.8948 \\
\hline Sargan test ( $p$-value) & 0.3724 & - & 0.5032 & - & 0.5432 & - & 0.6430 & - \\
\hline No. of countries & 35 & - & 35 & - & 35 & - & 35 & - \\
\hline No. of observations & 194 & - & 194 & - & 194 & - & 194 & - \\
\hline No. of instruments & 34 & - & 34 & - & 34 & - & 34 & - \\
\hline Turning point & $8.4 \%$ & - & $7.9 \%$ & - & $12.4 \%$ & - & $14.2 \%$ & - \\
\hline Lower bound slope & $3.7240 * * *$ & - & $4.6455 * * *$ & - & $12.9208 * * *$ & - & $13.8512 * * *$ & - \\
\hline Upper bound slope & $-2.8750 * * *$ & - & $-3.7018 * * *$ & - & $-7.5802 * * *$ & - & $-7.2986 * * *$ & - \\
\hline Overall $U$-test ( $t$-value) & $4.03 * * *$ & - & $6.17 * * *$ & - & $11.18 * * *$ & - & $7.89 * * *$ & - \\
\hline
\end{tabular}

Note: Time dummies were jointly significant and are not reported here to save space. Sargan test performed with non-robust standard errors. Dependent variable: Economic growth. Sample period: $1980-2015$ (5-year average)

$* * *, * *$ and $*$ denote significance level at $1 \%, 5 \%$ and $10 \%$

Following Soedarmono et al. (2017), we check the robustness of our results, running a static panel data model with GMM instrumental variables estimation. The estimation results presented in Table 1-A1, in Appendix 1, globally corroborate previous results of an inverted $U$-shaped relationship between financial development and economic growth.

Moreover, since our inverted $U$-shaped relationship result seemed incompatible with the results of Ibrahim and Alagidede (2018) of the existence of a threshold above (below) with which there is a positive and significant (nonsignificant) relationship between financial development and growth, we also applied a threshold estimation technique. However, Ibrahim and Alagidede estimate a static panel threshold model with annual data, while we control for endogeneity and purge business cycle frequencies from the data, estimating a dynamic panel threshold model with 5-year averaged data.

We follow the estimation procedure of Seo, Kim and Kim (2019) for a model with a kink in financial development. The threshold modelling strategy is becoming increasingly popular to search for non-linear relationships. As Law and Singh (2014) argue, the quadratic specification strategy imposes that the effect of finance on growth monotonically and symmetrically increases and decreases with the level of financial development. The threshold model, instead, allows for asymmetric behaviour with positive ranges of the relationship differing, in absolute impact, from that observed over negative ranges. The threshold model allows the relationship between finance and economic growth to be piecewise linear, with the levels of financial development indicators acting as a regime switching trigger. However, the estimation of this model requires a strictly balanced panel sample and, as a consequence, our sample is reduced to 23 countries. Therefore, this robustness exercise just seeks to check if the use of a threshold estimation method supports evidence of the non-linear pattern as seen in Ibrahim and Alagidede's (2018) results, rather than validate our results for the sample of 36 countries.

Table 2-A1, in Appendix 1, reports the results of the estimation of a dynamic threshold model using a GMM estimator, for a balanced sample of 23 SSA countries and for the period 1980-2015. ${ }^{12}$ Empirical findings show a hump-shaped relationship between financial development and economic growth: financial development has positive effects on growth only until a threshold level of $17 \%$, for the domestic credit to private sector ratio (\%GDP), and only up to $15.4 \%$ of GDP for liquid liabilities, hurting growth if these threshold levels are surpassed. The threshold levels for financial development indicators are still very small, only slightly higher than those from our quadratic baseline models and large sample. Hence, smoothing the business cycle effect and controlling for endogeneity with the estimation of a dynamic threshold model reinforce our findings in the large sample and the alternative estimation method, but do not support Ibrahim and Alagidede's (2018) results.

12.The 23 countries are: Burundi, Burkina Faso, Botswana, Central African Republic, Cote d'Ivoire, Cam:Burn, Demuratic Republic of the Cona A Cote d' Gambia, Kenya, Madagascar, Mauritius, Malawi, Niger, $\mathrm{Ni}$ Senegal, Sierra Leone, Swaziland, Togo and South Africa.
Except Sudan, all these countries are included in the sample of 29 SSA countries of Ibrahim and Alagidede (2018). 


\section{Conclusion}

There is now significant empirical literature that documents the existence of a hump-shaped relationship between financial development and economic growth in developed and developing countries where the financial system is relatively developed.

In face of the recent expansion of the financial sectors of SSA countries, it may be the case that even underdeveloped financial systems can become relatively oversized. In other words, it is possible that an inverted $U$-shaped relationship between financial development and economic growth can also be verified in less developed and lowincome countries, but on a much lower threshold-level of financial development compared to developed countries. We fill a gap in empirical literature by testing this hypothesis for a panel data in 36 SSA countries for the period 1980-2015.

Our empirical results suggest that more finance is not always better and may harm economic growth, even in countries with low levels of financial development. Moreover, most of the sample observations exceed the low threshold levels of financial development suggesting that further increase of the size of the financial sector may hamper economic growth in SSA countries. Therefore, in terms of policy implications, policymakers should focus more on formulating and implementing policies that create a favourable environment for the private sector to grow with the availability of the required finance, rather than just increasing the size of the financial sector. Measures to strengthen the quality of finance and other growthenhancing strategies, namely institutional quality and economic reforms, need to be undertaken.

Future research could shed more light on the non-linear relationship between finance and growth by examining more profoundly the role of mediating factors such as the quality of political institutions and by deconstructing the credit into consumption and investment credit. Investigating this nonlinear relationship in the individual SSA countries may be also of interest.

\section{Acknowledgements}

We are grateful to three anonymous peer reviewers of this journal for their helpful comments and suggestions.

\section{Competing interests}

The authors declare that they have no financial or personal relationships that may have inappropriately influenced them in the writing of this research article.

\section{Authors' contributions}

C.M.D.C.M, A.F.M.G.S. and P.D.D.V. contributed equally to this research article.

\section{Ethical considerations}

This article followed all ethical standards for research without direct contact with human or animal subjects.

\section{Funding information}

This research has been financed by Portuguese public funds through FCT - Fundação para a Ciência e a Tecnologia, I.P. - in the framework of project UID/ECO/04105/2019 (Celsa Machado).

\section{Data availability}

Data may be available from the authors on request.

\section{Disclaimer}

The views and opinions expressed in this article are those of the authors and do not necessarily reflect the official policy or position of any affiliated agency of the authors.

\section{References}

Acaravci, S.K., Ozturk, I. \& Acaravci, A., 2009, 'Financial development and economic growth: Literature survey and empirical evidence from sub-Saharan African countries', South African Journal of Economic and Management Sciences 12(1), 11-27. https://doi.org/10.4102/sajems.v12i1.258

Acemoğlu, D. \& Zilibotti, F., 1997, 'Was Prometheus unbound by chance? Risk, diversification and growth', Journal of Political Economy 105(4), 709-751. https:// doi.org/10.1086/262091

Adusei, M., 2013, 'Finance-growth nexus in Africa: A panel generalized method of moments (Gmm) analysis', Asian Economic and Financial Review 3(10), 1314-1324.

Adusei, M., 2019, 'The finance-growth nexus: Does risk premium matter?', International Journal of Finance \& Economics 24(1), 588-603. https://doi. org/10.1002/ijfe.1681

Anwar, S. \& Cooray, A., 2012, 'Financial development, political rights, civil liberties and economic growth: Evidence from South Asia', Economic Modelling 29(3) 974-981. https://doi.org/10.1016/j.econmod.2012.02.009

Arcand, J.L., Berkes, E. \& Panizza, U., 2015, 'Too much finance?', Journal of Economic Growth 20(2), 105-148. https://doi.org/10.1007/s10887-015-9115-2

Arellano, M. \& Bond, S., 1991, 'Some tests of specification for panel data: Monte Carlo evidence and an application to employment equations', The Review of Economic Studies 58(2), 277-297. https://doi.org/10.2307/2297968

Arellano, M. \& Bover, O., 1995, 'Another look at the instrumental variable estimation of error-components models', Journal of Econometrics 68(1), 29-51. https://doi.org/10.1016/0304-4076(94)01642-D

Beck, T., 2011, 'The role of finance in economic development: Benefits, risks, and politics', Discussion Paper 2011-141, Center for Economic Research, Tilburg University, Tilburg.

Beck, T., 2013, 'Finance, growth and fragility: The role of government', International Journal of Banking, Accounting and Finance 5(1-2), 49-77. https://doi. org/10.1504/IJBAAF.2013.058088

Beck, T., Levine, R. \& Loayza, N., 2000, 'Finance and the sources of growth', Journal of Financial Economics 58(1-2), 261-300. https://doi.org/10.1016/S0304 $405 \times(00) 00072-6$

Bencivenga, V.R. \& Smith, B.D., 1991, 'Financial intermediation and endogenous growth', The Review of Economic Studies 58(2), 195-209. https://doi. org/10.2307/2297964

Benczúr, P., Karagiannis, S. \& Kvedaras, V., 2019, 'Finance and economic growth: Financing structure and non-linear impact', Journal of Macroeconomics 62 103048. https://doi.org/10.1016/j.jmacro.2018.08.001

Bist, J.P., 2018, 'Financial development and economic growth: Evidence from a panel of 16 African and non-African low-income countries', Cogent Economics \& Finance 6(1), 1-17. https://doi.org/10.1080/23322039.2018.1449780

Blundell, R. \& Bond, S., 1998, 'Initial conditions and moment restrictions in dynamic panel data models', Journal of Econometrics 87(1), 115-143. https://doi. org/10.1016/S0304-4076(98)00009-8

Bolton, P., Santos, T. \& Scheinkman, J., 2016, 'Cream-skimming in financial markets', The Journal of Finance 71(2), 709-736. https://doi.org/10.1111/jofi.12385

Cecchetti, G. \& Kharroubi, E., 2012, 'Reassessing the impact of finance on growth', BIS Working Paper 381, Bank for International Settlements, Basel.

Deidda, L. \& Fattouh, B., 2002, 'Non-linearity between finance and growth', Economics Letters 74(3), 339-345. https://doi.org/10.1016/S0165-1765(01)00571-7 
Demetriades, P. \& Law, S.H., 2006, 'Finance, institutions and economic growth', International Journal of Finance and Economics 11(3), 245-260. https://doi. org/10.1002/ijfe.296

Demirgüç-Kunt, A. \& Klapper, L., 2012, 'Financial inclusion in Africa: An overview', World Bank Policy Research Working Paper 6088, June, World Bank, Washington, DC.

Demirgüç-Kunt, A., Feyen, E. \& Levine, R., 2013, 'The evolving importance of banks and securities markets', The World Bank Economic Review 27(3), 476-490. https:// doi.org/10.1093/wber/lhs022

Dombi, Á. \& Grigoriadis, T., 2020, 'State history and the finance-growth nexus: Evidence from transition economies', Economic Systems 44(1), 100738. https:// doi.org/10.1016/j.ecosys.2019.100738

Ductor, L. \& Grechyna, D., 2015, 'Financial development, real sector, and economic growth', International Review of Economics and Finance 37(C), 393-405. https:// doi.org/10.1016/j.iref.2015.01.001

Effiong, E., 2015, 'Financial development, institutions and economic growth: Evidence from sub-Saharan Africa', MPRA Paper 66085, University Library of Munich, Munich.

Ehigiamusoe, K.U. \& Lean, H.H., 2018, 'Finance-growth nexus: New insights from the West African Region' Emerging Markets Finance and Trade 54(11), 2596-2613. https://doi.org/10.1080/1540496X.2017.1364623

Feenstra, R.C., Inklaar, R. \& Timmer, M.P., 2015, 'The next generation of the Penn world table', American Economic Review 105(10), 3150-3182. https://doi. org/10.1257/aer.20130954

Fernandez, A. \& Tamayo, C.E., 2017, 'From institutions to financial development and growth: What are the links?', Journal of Economic Surveys 31(1), 17-57. https:// doi.org/10.1111/joes.12132

Gazdar, K., \& Cherif, M., 2015, 'Institutions and the finance-growth nexus: Empirical evidence from MENA countries', Borsa Istanbul Review 15(3), 137-160. https:// doi.org/10.1016/j.bir.2015.06.001

Greenwood, J. \& Jovanovic, B., 1990, 'Financial development, growth, and the distribution of income', Journal of Political Economy 98(5), 1076-1107. https:// doi.org/10.1086/261720

Hung, F.-S., 2009, 'Explaining the nonlinear effects of financial development on economic growth', Journal of Economics 97(1), 41-65. https://doi.org/10.1007/ s00712-008-0057-4

Hung, F.-S. \& Cothren, R., 2002, 'Credit market development and economic growth' Journal of Economics and Business 54(2), 219-237. https://doi.org/10.1016/ Journal of Economics and
S0148-6195(01)00063-7

Ibrahim, M. \& Alagidede, P., 2018, 'Nonlinearities in financial development-economic growth nexus: Evidence from sub-Saharan Africa', Research in Internationa Business and Finance 46, 95-104. https://doi.org/10.1016/j.ribaf.2017.11.001

Inoue, T. \& Hamori, S., 2016, 'Financial access and economic growth: Evidence from sub-Saharan Africa', Emerging Markets Finance and Trade 52(3), 743-753. https:// doi.org/10.1080/1540496X.2016.1116282

King, R.G. \& Levine, R., 1993a, 'Finance and growth: Schumpeter might be right', The Quarterly Journal of Economics 108(3), 717-737. https://doi.org/10.2307/2118406

King, R.G. \& Levine, R., 1993b, 'Finance, entrepreneurship and growth', Journal of MonetaryEconomics 32(3), 513-542. https://doi.org/10.1016/0304-3932(93)90028-E

Law, S.H., Lee, W.C. \& Singh, N., 2018, 'Revisiting the finance-innovation nexus: Evidence from a non-linear approach', Journal of Innovation \& Knowledge 3(3), 143-153. https://doi.org/10.1016/j.jik.2017.02.001

Law, S.H. \& Singh, N., 2014, 'Does too much finance harm economic growth?', Journal of Banking \& Finance 41, 36-44. https://doi.org/10.1016/j.jbankfin.2013.12.020
Levine, R., 2005, 'Finance and growth: Theory and evidence', in P. Aghion \& S.N. Durlauf (eds.), Handbook of economic growth, pp. 865-934, Elsevier, Amsterdam.

Levine, R., Loayza, N. \& Beck, T., 2000, 'Financial intermediation and growth: Causality and causes', Journal of Monetary Economics 46(1), 31-77. https://doi. org/10.1016/S0304-3932(00)00017-9

Lind, J.T. \& Mehlum, H., 2010, 'With or without U? The appropriate test for a U-shaped relationship', Oxford Bulletin of Economics and Statistics 72(1), 109-118. https:// doi.org/10.1111/j.1468-0084.2009.00569.x

Loyaza, N.V. \& Rancière, R., 2006, 'Financial development, financial fragility, and growth', Journal of Money Credit and Banking 38(4), 1051-1076. https://doi. org/10.1353/mcb.2006.0060

Ngongang, E., 2015, 'Financial development and economic growth in sub-Saharan Africa: A dynamic panel data analysis', European Journal of Sustainable Development 4(2), 369-378. https://doi.org/10.14207/ejsd.2015.v4n2p369

Pagano, M., 1993, 'Financial markets and growth: An overview', European Economic Review 37(2-3), 613-622. https://doi.org/10.1016/0014-2921(93)90051-B

Panizza, U., 2014, 'Financial development and economic growth: Known knowns, known unknowns, and unknown unknowns', Revue d'économie du Développement 22(HS02), 35-65. https://doi.org/10.3917/edd.hs02.0035

Pasali, S., 2013, 'Where is the cheese? Synthesizing a giant literature on causes and consequences of financial sector development', World Bank Policy Research Working Paper 6655, October, World Bank, Washington, DC.

Popov, A., 2017, 'Evidence on finance and economic growth', Working Paper Series No. 2115, December, European Central Bank, Frankfurt.

Rioja, F. \& Valey, N., 2004a, 'Does one size fit all? A reexamination of the finance and growth relationship', Journal of Development Economics 74(2), 429-447. https:// doi.org/10.1016/j.jdeveco.2003.06.006

Rioja, F. \& Valey, N., 2004b, 'Finance and the sources of growth at various stages of economic development', Economic Inquiry 42(1), 127-140. https://doi. org/10.1093/ei/cbh049

Samargandi, N., Fidrmuc, J. \& Ghosh, S., 2015, 'Is the relationship between financial development and economic growth monotonic? Evidence from a sample of middle income countries', World Development 68, 66-81. https://doi. org/10.1016/j.worlddev.2014.11.010

Seo, M.H., Kim, S. \& Kim, Y.-J., 2019, 'Estimation of dynamic panel threshold model using stata', Papers 1902.10318, arXiv.org, Division of Economics Seoul National University, Seoul.

Slesman, L., Baharumshah, A.Z. \& Azman-Saini, W.N.W., 2019, 'Political institutions and finance-growth nexus in emerging markets and developing countries: A tale of one threshold', The Quarterly Review of Economics and Finance 72, 80-100. https://doi.org/10.1016/j.qref.2019.01.017

Soedarmono, W., Hasan, I., \& Arsyad, N., 2017, 'Non-linearity in the finance-growth nexus: Evidence from Indonesia', International Economics 150, 19-35. https://doi. org/10.1016/j.inteco.2016.11.003

Swamy, V. \& Dharani, M., 2019, 'The dynamics of finance-growth nexus in advanced economies', Review of Economics and Finance 64(1), 122-146. https://doi. org/10.1016/j.iref.2019.06.001

Tobin, J., 1984, 'On the efficiency of the financial system', Lloyds Bank Review 153, $1-15$.

Windmeijer, F., 2005, 'A finite sample correction for the variance of linear efficient two-step GMM estimators', Journal of Econometrics 126(1), 25-51. https://doi. org/10.1016/j.jeconom.2004.02.005 


\section{Appendix 1}

TABLE 1-A1: Generalised method of moments instrumental variables estimations.

\begin{tabular}{|c|c|c|c|c|c|c|c|c|}
\hline \multirow[t]{3}{*}{ Variable } & \multicolumn{4}{|c|}{ Financial development, FD $\equiv$ DC } & \multicolumn{4}{|c|}{ Financial development, FD $\equiv \mathrm{M} 3$} \\
\hline & \multicolumn{2}{|c|}{ Model 5DC } & \multicolumn{2}{|c|}{ Model 6DC } & \multicolumn{2}{|c|}{ Model 5M3 } & \multicolumn{2}{|c|}{ Model 6M3 } \\
\hline & Coefficient & $\begin{array}{c}\text { Robust standard } \\
\text { errors }\end{array}$ & Coefficient & $\begin{array}{c}\text { Robust standard } \\
\text { errors }\end{array}$ & Coefficient & $\begin{array}{c}\text { Robust standard } \\
\text { errors }\end{array}$ & Coefficient & $\begin{array}{l}\text { Robust standard } \\
\text { errors }\end{array}$ \\
\hline InGDPO & $-6.5998^{* * *}$ & 1.3183 & $-5.4440 * * *$ & 1.5398 & $-6.1139 * * *$ & 1.2346 & $-5.6059 * * *$ & 1.3589 \\
\hline $\operatorname{lnFD}$ & 0.2032 & 0.8809 & $1.2114^{*}$ & 0.6720 & 3.7428 & 2.7086 & $6.9515^{* * *}$ & 2.6325 \\
\hline $\ln F D^{2}$ & - & - & -0.4324 & - & - & - & $-1.8660 * * *$ & - \\
\hline $\operatorname{lnGCF}$ & 0.3441 & 0.6416 & 0.1228 & 0.6324 & 0.3112 & 0.9005 & 0.1514 & 0.5485 \\
\hline Inflation & $-0.0006^{*}$ & 0.0003 & $-0.0008 * * *$ & 0.0003 & $-0.0014^{* *}$ & 0.0006 & -0.0005 & 0.0004 \\
\hline IL & $3.8173^{* * *}$ & 1.0804 & $4.4035^{* * *}$ & 1.1362 & $4.1573^{* * *}$ & 1.4072 & $3.7591^{* * *}$ & 1.1964 \\
\hline $\mathrm{InHC}$ & 0.8507 & 4.2723 & 2.2195 & 4.3066 & 1.5981 & 5.2880 & 2.9854 & 4.4475 \\
\hline Cragg-Donald Wald $F$ statistic & 20.8300 & - & 4.0960 & - & 3.2850 & - & 1.6920 & - \\
\hline Hansen $J$ statistic & 0.1300 & - & 0.5640 & - & 0.2150 & - & 1.8900 & - \\
\hline No. of countries & 35 & - & 35 & - & 35 & - & 35 & - \\
\hline No. of observations & 159 & - & 159 & - & 159 & - & 159 & - \\
\hline Lower bound slope & - & - & $2.6106^{* *}$ & - & - & - & $10.8042^{* * *}$ & - \\
\hline Upper bound slope & - & - & -3.1243 & - & - & - & $-10.2155^{* * *}$ & - \\
\hline Overall $U$-test ( $t$-value) & - & - & 1.07 & - & - & - & $2.51 * * *$ & - \\
\hline
\end{tabular}

Note: Time dummies were jointly significant and are not reported here to save space. Dependent variable: Economic growth. Sample period: 1980-2015 (5-year average).

$* * *, * *$ and $*$ denote significance level at $1 \%, 5 \%$ and $10 \%$.

TABLE 2-A1: Dynamic panel threshold model estimations.

\begin{tabular}{|c|c|c|c|c|}
\hline \multirow[t]{2}{*}{ Variable } & \multicolumn{2}{|c|}{ FD $\equiv$ DC: Model 7DC } & \multicolumn{2}{|c|}{ FD $\equiv$ M3: Model 7M3 } \\
\hline & Coefficient & Robust standard error & Coefficient & Robust standard error \\
\hline Growth $_{t-1}$ & $-0.1633 * * *$ & 0.0606 & -0.0681 & 0.0636 \\
\hline InGDPO & $-7.2356 * * *$ & 0.4375 & $-7.9253^{* * *}$ & 0.4290 \\
\hline $\ln F D$ & $1.8806^{* * *}$ & 0.3102 & $2.9177^{* * *}$ & 0.5350 \\
\hline InFD (kink slope) & $-3.7911 * * *$ & 1.4429 & $-5.2978 * * *$ & 1.5517 \\
\hline $\operatorname{lnGCF}$ & $0.8530^{*}$ & 0.4793 & $-1.3118^{* *}$ & 0.6185 \\
\hline inflation & $-0.0006 * * *$ & 0.0001 & $-0.0014^{* * *}$ & 0.0001 \\
\hline IL & $6.6744 * * *$ & 2.2592 & $12.0476^{* * *}$ & 1.4004 \\
\hline Threshold of FD & $17.0 \% * * *$ & - & $15.4 \% * * *$ & - \\
\hline Number of countries & 23 & - & 23 & - \\
\hline Number of observations & 161 & - & 161 & - \\
\hline
\end{tabular}

Note: Dependent variable: Economic growth. Sample period: 1980-2015 (5-year average).

${ }^{* * *},{ }^{* *}$ and ${ }^{*}$ denote significance level at $1 \%, 5 \%$ and $10 \%$. 